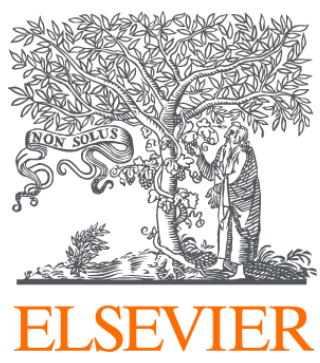

Since January 2020 Elsevier has created a COVID-19 resource centre with free information in English and Mandarin on the novel coronavirus COVID-

19. The COVID-19 resource centre is hosted on Elsevier Connect, the company's public news and information website.

Elsevier hereby grants permission to make all its COVID-19-related research that is available on the COVID-19 resource centre - including this research content - immediately available in PubMed Central and other publicly funded repositories, such as the WHO COVID database with rights for unrestricted research re-use and analyses in any form or by any means with acknowledgement of the original source. These permissions are granted for free by Elsevier for as long as the COVID-19 resource centre remains active. 


\title{
Leading in a Time of Chaos
}

\author{
Rose O. Sherman, EdD, RN, NEA-BC, FAAN
}

$\mathbf{T}$ he COVID-19 pandemic has produced a classic example of a VUCA (volatility, uncertainty, complexity, ambiguity) environment in health care. Nurse leaders have had to move into uncharted waters in a volatile environment characterized by rapid, sudden, and constant change. Few of us would have predicted that many of the following practices could become commonplace in health care:

- Conversion of many clinical areas into intensive care units.

- The rise in patient acuity, patient deaths, and length of stay with the treatment of COVID-19 patients.

- The postponement of most elective surgeries and procedures.

- Staff and nurse leader rapid redeployment to clinical areas outside their expertise.

- Shortages of personal protective equipment and changes in infection control measures from past best practices to good enough.

- Rapid-cycle education around ventilator management.

- A movement from patient-centered care to a public health population management model.

- Change in the care delivery model from a primary care approach to team nursing.

- A rapid rise in the utilization of telehealth to meet a wide range of health needs with acceptance from both patients and payers.

- Playing celebratory music when COVID-19 patients are discharged.

Throughout the crisis, there has been uncertainty in the accuracy of information and the projected outcomes of the pandemic. Decision making is fraught with complexity as there is a multiplicity of variables and many unknowns. There is ambiguity moving forward stemming from a lack of clarity about how this event will transform health care and the global economy. It has produced an extraordinary level of disruption and a recognition that the future will be much more unpredictable than the past. Health care will never be the same.

David Peterson, ${ }^{1}$ Google's head of executive coaching and leadership, noted just a few months before the pandemic that the requirements of leadership change in times of chaos. When things are stable, leaders can be effective by optimizing performance around current needs. But when things become unstable, leaders will be more successful if they are willing to suboptimize what is currently working, and instead try new things and take risks. There are often no instructions or playbook on how to best proceed in chaotic environments where cause and effect are unclear.

Stabilizing the system is challenging. Decisions need to be made more quickly, driven by a clear set of values and principles. Erica Jong (From Brainy Quote https:// www.brainyquote.com/quotes/erica_jong_124695) once noted that if you don't risk anything - you risk more. Surfing on the edge of chaos requires letting go of things that may have served us well in the past. It also requires real-time leadership reflection to try to make sense of new data and unexpected events.

Leadership never matters more than in times of crisis. Crises force us to abandon an urge to simplify things. Leaders have to be willing to move to the edge with their decision making when the direction and outcomes are not always clear. There are high levels of fear, confusion, and anxiety.

Peterson ${ }^{1}$ contends that when leaders allow themselves to fully embrace leading through the chaos, they will emerge with greater insight and capabilities. Chaos reminds us that we are human, leading to characterbuilding experiences and greater empathy. Leaders like Peterson work hard to create chaotic simulated experiences, but this one has been real time and far exceeds anything that could happen in simulation. Winston Churchill ${ }^{2}$ is noted for his observation that we should never let a crisis go to waste. As we move forward, we need to make sure that we capture our lessons learned and that they serve us well moving forward.

\section{REFERENCES}

1. Peterson PD. The DNA of VUCA: Coaching Leaders to Thrive in Chaos, Complexity, and Exponential Change. Webinar 2019 World Business Executive Coaching Conference. Available at: https://www.wbecs.com/wbecs19/presenter/david-b-peterson/. Accessed November 21, 2019.

2. Larson E. The Splendid and the Vile: A Saga of Churchill, Family, and Defiance During the Blitz. Crown Books. 2020.

Editor-in-Chief Rose O. Sherman, EdD, RN, NEA-BC, FAAN, is Professor Emeritus at Florida Atlantic University on Mast, and adjunct professor of nursing at Marian K. Shaughnessy Leadership Academy, Case Western Reserve University, in Cleveland, Ohio. She can be reached at rose.sherman@gmail.com.

1541-4612/2020/\$ See front matter Copyright 2020 by Elsevier Inc. All rights reserved. https://doi.org/10.1016/j.mnl.2020.04.006 